\title{
Seroprevalence and Influence of Bovine Leukemia Virus on the Incidence of Mastitis in Dairy Herds*
}

\author{
Ítalo Câmara de Almeida', Sayanne Luns Hatum de Almeida', Graziela Barioni', Dirlei Molinari Donatele', \\ Renata Cogo Clipes², Leonardo Siqueira Glória ${ }^{3} \&$ Paula Alessandra Di Filippo ${ }^{3}$
}

\begin{abstract}
Background: The enzootic bovine leukosis (EBL) is a viral disease with a chronic aspect and its etiological agent is an oncogenic deltaretrovirus called bovine leukemia virus (VLB). It has a wide distribution in dairy cattle herds, and it may take several years before the first clinical manifestations occur. Animals seropositive for VLB are more susceptible to developing infectious diseases such as mastitis. The objective of this study was to evaluate the seroprevalence of EBL, the prevalence of mastitis, the possible association between leukosis and mastitis, and the risk factors related to leukosis in municipalities of the Caparaó region of Espírito Santo, Brazil.

Materials, Methods \& Results: The prevalence of enzootic bovine leukosis and its association with mastitis were evaluated in an 854 clinically healthy crossbred (Bos tauros tauros $\mathrm{x}$ Bos taurus indicus) dairy cows were used, in different lactation phases, from farms located in the 12 municipalities that compose the Caparao Capixaba micro-region, in the southern part of Espírito Santo, Brazil, in the period from February to December 2015. The seroprevalence of EBL was determined by the agar gel immunodiffusion test, the presence of clinical mastitis was ascertained by the black background mug test and of subclinical mastitis by the CMT. The reuse of needles, type of milking, reproductive management, calf mortality, presence of reproductive problems and milk yield were the risk factors assessed. The association between the variables was estimated by the odds ratio (95\% confidence interval). The significance of the associations was determined by the Chi-square test. The prevalence of EBL, clinical and subclinical mastitis was $56.79 \%, 5.50 \%$ and $43.55 \%$, respectively. There was a positive association between the EBL virus and the presence of subclinical mastitis $(P<0.05, \mathrm{OR}=1.41, \mathrm{CI}$ $=1.07-1.86)$. The reuse of disposable needles $(\mathrm{OR}=1.92, \mathrm{CI}=1.46-2.53)$, mechanical milking $(\mathrm{OR}=2.03, \mathrm{CI}=1.34$ $3.08)$, calf mortality $(\mathrm{OR}=2.39 ; \mathrm{CI}=1.25-4.55)$ and the presence of reproductive problems $(\mathrm{OR}=1.62 ; \mathrm{CI}=1.23-2.14)$ were considered risk factors associated with LEB $(P<0.05)$

Discussion: Enzootic bovine leukosis is disseminated in the dairy herds in the municipalities the study. The lack of knowledge about EBL among farmers and the failure to adopt measures for its control and elimination favor the appearance of new cases in the herd. Factors such as animal age, absence of exams when purchasing animals, reuse of gloves for rectal palpation and needles, contribute to dissemination of the infection. The economic losses associated with subclinical mastitis can even be greater than those caused by clinical mastitis. The differences for prevalence of clinical mastitis can be associated with the breeding system, type of management, intensification and level of production. In this context, we noted a much larger number of animals with subclinical infection, where the losses may not be perceptible to the farmers. It is concluded that EBL is widespread in dairy herds of the municipalities of Caparaó Espírito Santo's region. The prevalence of clinical and subclinical mastitis is high in some cities surveyed. The presence of EBL increases the chances of developing subclinical mastitis. The reuse of disposable needles and mechanical milking were considered risk factors associated with EBL. Seroreagent animals for EBL are more likely to present calf mortality and reproductive problems. It is necessary to discuss the best sanitary management system for the region, with a better economic and social response and then carry out the elaboration of educational and implementation measures, through technical assistance.
\end{abstract}

Keywords: cows, enzootic bovine leukosis, milk, immunosuppression.

DOI: $10.22456 / 1679-9216.109458$

Received: 10 November 2020

Accepted: 27 December 2020

Published: 26 January 2021

*Article based on a Dissertation submitted by the senior author in partial fulfillment of requirements for the Doctor's Degree - Programa de Pós-Graduação em Ciência Animal da Universidade Estadual do Norte Fluminense Darcy Ribeiro (UENF), Campos dos Goytacazes, RJ, Brazil. 'Departamento de Medicina Veterinária, Universidade Federal do Espírito Santo (UFES), Alegre, ES, Brazil. ${ }^{2}$ Departamento de Zootecnia, Instituto Federal do Espírito Santo (IFES), Alegre. ${ }^{3}$ Pós-Graduação em Ciência Animal, UENF, Campos dos Goytacazes, RJ, Brazil. CORRESPONDENCE: I.C. Almeida [almeidaicvet@ gmail.com]. Departamento de Medicina Veterinária - UFES). Alto Universitário s/n. CEP 29500-000 Alegre, ES, Brazil. 


\section{INTRODUCTION}

The Caparaó region, located in the southern part of the state of Espírito Santo, Brazil, is important for milk production. In 2015, the region accounted for about $14 \%$ of the state's milk output [14]. Despite the expansion of dairy farming in the region, there are few official animal health programs, and farmers suffer from productive losses due to infecto-contagious diseases, among them enzootic bovine leukosis (EBL) and mastitis. EBL is caused by the bovine leukemia virus (BLV), a retrovirus that mainly infects the defense cells, especially B cells [13].

Approximately $40 \%$ of carriers will develop persistent lymphocytosis, and under $5 \%$ will develop malignant lymphosarcoma, the clinical form of the disease [27]. Seroreactive animals to EBL are more susceptible to developing infectious diseases such as mastitis due to the immunosuppression caused by the virus [17]. The positive correlation between EBL and the presence of mastitis (both clinical and subclinical) indicates that the higher the number of reactive animals in a herd, the greater will be the presence of mastitis [23].

Enzootic bovine leukosis occurs throughout Brazil, causing a reduction of up to $3 \%$ in milk yield by affected animals [9]. Its prevalence is varied in Brazilian states, with $56.34 \%$ in Paraná [4], 24.1\% in Pernambuco [7] and $11.2 \%$ in São Paulo [10]. To expand knowledge in this respect, the objective of this study was to evaluate the seroprevalence of enzootic bovine leukosis, the prevalence of clinical and subclinical mastitis, the possible association between leukosis and mastitis, and the risk factors related to leukosis in municipalities of the Caparaó region of Espírito Santo, Brazil.

\section{MATERIALS AND METHODS}

\section{Study population}

A total of 854 clinically healthy crossbred (Bos taurus taurus x Bos taurus indicus) dairy cows were used, in different lactation phases, from farms located in the 12 municipalities (Alegre, Bom Jesus do Norte, Divino de São Lourenço, Dores do Rio Preto, Guaçuí, Ibatiba, Ibitirama, Irupi, Iúna, Jerônimo Monteiro, Muniz Freire and São José do Calçado) that compose the Caparaó Capixaba micro-region $\left(20^{\circ} 26^{\prime} 5^{\prime \prime} \mathrm{S}\right.$ and $\left.41^{\circ} 47^{\prime} 2^{\prime \prime} \mathrm{W}\right)$, in the southern part of Espírito Santo, Brazil, in the period from February to December 2015. Animals from 69 farms were evaluated at random, from 5 farms per municipality, except for Alegre and Jerônimo Monteiro, where 9 and 10 farms were evaluated, respectively.

\section{Serological test for leukosis}

Whole blood samples were collected in a vacuum collection system from all the lactating cows by puncture of the medial coccygeal vein. The blood samples were placed in tubes without anticoagulant and taken to the laboratory in isothermal chests. The samples were centrifuged at $200 \mathrm{~g}$ for $5 \mathrm{~min}$ and the serum was fractionated in $1.5 \mathrm{~mL}$ polyethylene tubes and stored at $-80^{\circ} \mathrm{C}$. The presence of EBL was diagnosed by agar gel immunodiffusion (AGID), using Noble Agar ${ }^{1}$ and with Tecpar antigens ${ }^{2}$.

\section{Test for mastitis}

The presence of clinical mastitis was determined by identifying the clinical signs of inflammation of the mammary gland and by the black background mug test. In turn, subclinical mastitis was diagnosed by the California mastitis test (CMT). The animals were considered positive for clinical or subclinical mastitis when there was alteration in the mug or California test, respectively, in at least one of the teats.

\section{Study of risk factors}

The variables analyzed were prevalence of EBL, clinical mastitis and subclinical mastitis and the possible relation between EBL and mastitis. A questionnaire was administered to the farmers referring to reuse of needles, type of milking (manual or mechanical), reproductive management (artificial insemination or natural mounting), calf mortality and whether the farm had reproductive problems. The farms were classified according to milk production as small (up to $53 \mathrm{~L} /$ day), medium (from 54 to $133 \mathrm{~L} /$ day) or large (>133 L/day) [5].

\section{Statistical analysis}

The number of samples was calculated according to the formula below:

$$
n=\operatorname{deff} \times \frac{N p q}{\frac{d^{2}}{1.96^{2}}(n-1)+p q}
$$


Where:

$n=$ sample size;

deff = design effect;

$N=$ population size;

$p=$ estimated proportion;

$q=1-\mathrm{p}$

$d=$ absolute precision level.

Using an anticipated frequency of $50 \%$ for the diseases (leukosis and mastitis), confidence limit of $5 \%$, confidence interval of $99 \%$ and herd size in Espírito Santo of 2,223,531 head of cattle in 2015 [1], we calculated the minimum sample size as 664 animals. A total of 854 animals were evaluated.

The statistical results were tabulated descriptively and the associations between the variables were estimated by the odds ratio (OR) with a confidence interval of $95 \%$. The chi-squared test was used to verify the significance of the associations $(P<0.05)$. All the calculations were performed with the OpenEpi 3.01 software $^{3}$.

\section{RESULTS}

Of the 854 cows evaluated, 47 (5.50\%) were diagnosed with clinical mastitis and $372(43.55 \%)$ with subclinical mastitis (Table 1). Mean seroprevalence of $56.79 \%$ (485/854) was observed for EBL (Table 2). There was a significant association between EBL and the presence of subclinical mastitis, but no association between EBL and clinical mastitis (Table 3).

Of the 69 farms assessed, 7 were classified as small, 22 as medium and 40 as large, and the average numbers of cows submitted to milking were 6,8 and 17 , respectively. The prevalence of EBL was higher in farms with larger milk output (Table 4). The reuse of disposable needles and mechanical milking were considered risk factors associated with EBL $(P<0.05)$. Animals seroreactive to EBL had a higher probability of giving birth to dead calves and of presenting reproductive problems $(P<0.05)$. The reproductive management by natural mounting and milk production level were not considered risk factors associated with EBL (Table 5).

Table 1. Prevalence (\%) of clinical and subclinical mastitis in crossbred dairy cows in the municipalities that compose the Caparaó region, Espírito Santo (February to December 2015).

\begin{tabular}{|c|c|c|c|c|c|c|}
\hline \multirow{2}{*}{ Municipality } & \multicolumn{3}{|c|}{ Clinical Mastitis } & \multicolumn{3}{|c|}{ Subclinical Mastitis } \\
\hline & + & $\mathrm{n}$ & $\%$ & + & $\mathrm{n}$ & $\%$ \\
\hline Divino de São Lourenço & 3 & 63 & 4.76 & 15 & 63 & 23.80 \\
\hline Bom Jesus do Norte & 0 & 38 & 0 & 12 & 38 & 31.57 \\
\hline Ibatiba & 2 & 57 & 3.50 & 23 & 57 & 40.35 \\
\hline Dores do Rio Preto & 5 & 84 & 5.95 & 35 & 84 & 41.66 \\
\hline São José do Calçado & 2 & 45 & 4.44 & 19 & 45 & 42.22 \\
\hline Jerônimo Monteiro & 8 & 137 & 5.83 & 58 & 137 & 42.33 \\
\hline Muniz Freire & 4 & 75 & 5.33 & 32 & 75 & 42.66 \\
\hline Guaçuí & 2 & 36 & 5.55 & 16 & 36 & 44.44 \\
\hline Irupi & 3 & 35 & 8.57 & 16 & 35 & 45.71 \\
\hline Ibitirama & 5 & 72 & 6.94 & 33 & 72 & 45.83 \\
\hline Alegre & 11 & 143 & 7.69 & 72 & 143 & 50.34 \\
\hline Iúna & 2 & 69 & 2.89 & 41 & 69 & 59.42 \\
\hline Total & 47 & 854 & 5.50 & 372 & 854 & 43.55 \\
\hline
\end{tabular}

$(+)=$ number of positive animals in at least one teat; $(\mathrm{n})=$ number of animals evaluated; $(\%)=$ prevalence of clinical and subclinical mastitis. 
I.C. Almeida, S.L.H. Almeida, G. Barioni, et al. 2021. Seroprevalence and Influence of Bovine Leukemia Virus on the Incidence of Mastitis in Dairy Herds.

Acta Scientiae Veterinariae. 49: 1783.

Table 2. Seroprevalence (\%) of enzootic bovine leukosis (EBL) by the agar gel immunodiffusion assay in crossbred dairy cattle in the municipalities that compose the Caparaó region, Espírito Santo (February to December 2015).

\begin{tabular}{ccccc}
\hline Municipality & Reactive cows & Non-reactive cows & Total cows & Seroprevalence of EBL $(\%)$ \\
\hline Ibatiba & 11 & 46 & 57 & 19.29 \\
Bom Jesus do Norte & 9 & 29 & 38 & 23.68 \\
Dores do Rio Preto & 41 & 43 & 84 & 48.80 \\
Divino de São Lourenço & 32 & 31 & 63 & 50.79 \\
São José do Calçado & 24 & 21 & 45 & 53.33 \\
Guaçuí & 20 & 16 & 36 & 55.55 \\
Jerônimo Monteiro & 77 & 60 & 137 & 56.20 \\
Iúna & 43 & 26 & 143 & 62.31 \\
Alegre & 95 & 48 & 75 & 66.43 \\
Muniz Freire & 51 & 24 & 72 & 68.00 \\
Ibitirama & 52 & 20 & 35 & 72.22 \\
Irupi & 30 & 569 & 854 & 87.71 \\
\hline Total cows evaluated & 485 & 369 & 56.79 \\
\hline
\end{tabular}

Table 3. Association between enzootic bovine leukosis and the presence of clinical mastitis and subclinical mastitis in crossbred dairy cattle in the municipalities that compose the Caparaó region, Espírito Santo (February to December 2015).

\begin{tabular}{cccc}
\hline & Odds Ratio & Confidence Interval (95\%) & $P$-value \\
\hline Clinical Mastitis & 1.85 & $0.97-3.51$ & $0.05604^{\mathrm{ns}}$ \\
Subclinical Mastitis & 1.41 & $1.07-1.86$ & $0.01348^{*}$ \\
\hline
\end{tabular}

$P$-value/chi-squared test; ns= Not Significant difference; $*$ Significant difference $(P<0.05)$.

Table 4. Percentage distribution of the possible variables associated with the seroprevalence (\%) of enzootic bovine leukosis (EBL) in crossbred dairy cattle in the municipalities that compose the Caparaó region, Espírito Santo (February to December 2015).

\begin{tabular}{|c|c|c|c|}
\hline Variable & Animals tested & Seroreactive to EBL & Seroprevalence of EBL (\%) \\
\hline \multicolumn{4}{|l|}{ Milk production } \\
\hline Small (up to $53 \mathrm{~L} /$ day) & 41 & 20 & 48.78 \\
\hline Medium (54 to $133 \mathrm{~L} /$ day) & 167 & 86 & 51.49 \\
\hline Large (>133 L/day) & 646 & 379 & 58.66 \\
\hline \multicolumn{4}{|l|}{ Reuse of needles } \\
\hline Yes & 467 & 299 & 64.02 \\
\hline No & 387 & 186 & 48.06 \\
\hline \multicolumn{4}{|l|}{ Calf mortality } \\
\hline Yes & 52 & 39 & 75.00 \\
\hline No & 802 & 446 & 55.61 \\
\hline \multicolumn{4}{|l|}{ Reproductive problems } \\
\hline Yes & 401 & 253 & 63.09 \\
\hline No & 453 & 232 & 51.21 \\
\hline \multicolumn{4}{|l|}{ Type of milking } \\
\hline Mechanical & 750 & 442 & 58.93 \\
\hline Manual & 104 & 43 & 41.34 \\
\hline \multicolumn{4}{|l|}{ Reproductive management } \\
\hline Artificial insemination & 521 & 308 & 59.11 \\
\hline Natural mounting & 333 & 177 & 53.15 \\
\hline
\end{tabular}


Table 5. Variables associated with the seroprevalence of enzootic bovine leukosis (EBL) in crossbred dairy cattle in the municipalities that compose the Caparaó region, Espírito Santo (February to December 2015).

\begin{tabular}{cccc}
\hline Variable & Odds Ratio & Confidence Interval (95\%) & $P$-value \\
\hline Reuse of disposable needles & 1.92 & $1.46-2.53$ & $0.000002758^{*}$ \\
Mechanical milking & 2.03 & $1.34-3.08$ & $0.0006912^{*}$ \\
Calf mortality & 2.39 & $1.25-4.55$ & $0.006234^{*}$ \\
Reproductive problems & 1.62 & $1.23-2.14$ & $0.0004703^{*}$ \\
Natural mounting & 0.78 & $0.59-1.03$ & $0.08618^{\mathrm{ns}}$ \\
Production level (small) & 0.71 & $0.38-1.33$ & $0.2900^{\mathrm{ns}}$ \\
Production level (medium) & 0.76 & $0.54-1.07$ & $0.1236^{\mathrm{ns}}$ \\
Production level (large) & 1.36 & $0.99-1.86$ & $0.05099^{\mathrm{ns}}$ \\
\hline
\end{tabular}

$P$-value obtained by the chi-squared test; $*$ Significant difference $(P<0.05)$. ns $=$ Not Significant difference.

\section{DISCUSSION}

Acceptable values for prevalence of clinical mastitis in dairy herds are between 2 and 5\% [22]. A study conducted with crossbred cows in the Brazilian state of Pará revealed prevalence of $4.6 \%$ [21], while another found $10.5 \%$ in the state of Minas Gerais [20]. Such differences can be associated with the breeding system, type of management, intensification and level of production.

The indices of subclinical mastitis in this study varied from $23.80 \%$ to $59.42 \%$ (Table 1). A previous study carried out in the municipality of Alegre revealed prevalence of $47.68 \%$ for subclinical mastitis [29], a value similar to that of the present study, of $50.34 \%$ (Table 1). In the state of Rio de Janeiro, subclinical mastitis prevalence of $20.63 \%$ was observed [11]. The economic losses associated with subclinical mastitis can even be greater than those caused by clinical mastitis [8]. In this context, we noted a much larger number of animals with subclinical infection, where the losses may not be perceptible to the farmers. The reduction in milk yield in function of subclinical mastitis can amount to as much a 28 liters/cow/day [30].

There was large fluctuation of the seroprevalence of EBL (19.29 to 87.71\%) in the municipalities evaluated (Table 2). Similar findings were reported in other Brazilian states: $56.34 \%$ in Paraná [4], 24.1\% in Pernambuco [7] and $11.2 \%$ in São Paulo [10]. EBL is a notifiable disease according to the World Animal Health Organization (OIE) and has already been notified in Canada, United States, Germany, Portugal, Argentina and Chile [19]. Seroprevalence of 27.9\% was reported in a herd composed of 409 dairy cows in the municipality de Alegre [28]. The average for that municipality in our study $(66.43 \%$, Table 2$)$ was much higher. In the municipality de Anchieta, Espírito Santo, seroprevalence of $21.86 \%$ (204/933) was reported in beef cattle at slaughter [3]. The lack of knowledge about EBL among farmers and the failure to adopt measures for its control and elimination favor the appearance of new cases in the herd. Factors such as animal age, absence of exams when purchasing animals, reuse of gloves for rectal palpation and needles, contribute to dissemination of the infection [24].

In this study, animals seroreactive to EBL presented an increase up to 1.37 -fold of subclinical mastitis (Table 3). Similar findings were reported for cows in different stages of infection by BLV [26]. In this study, we observed higher prevalence of subclinical mastitis in animals carrying EBL in comparison with negative animals. This finding can be associated with the immunosuppression triggered by the BLV, predisposing animals to secondary diseases [17]. Unlike observed in this present study, an association was found between EBL and clinical mastitis $(P=0.047)$ in a study conducted in Minas Gerais [2]. However, those results do not allow claiming that the association was a factor that increased or decreased the risk, since the confidence interval varied from 0.111 - 1.027.

The reuse of disposable needles was a factor that increased the risks of occurrence of EBL (Table $5)$. In this context, this practice was observed on 32 $(46.37 \%)$ of the 69 farms evaluated, mainly for the application of oxytokin. Of the animals evaluated, $54.68 \%$ (467/854) received oxytokin to facilitate the ejection of milk (Table 4 ). The reuse of needles, as well as obstetrical gloves, is a common practice among dairy farmers, and should be discouraged [24].

Mechanical milking was also found to be a risk factor for the occurrence of EBL. The animals submit- 
ted to mechanical milking had up to twice the chance of being seroreactive to EBL (Table 5). Those findings corroborate those described in the state of Tocantins, where mechanically milked cows presented EBL prevalence of $54 \%$ in comparison with $36.3 \%$ among those milked manually [12]. Greater intensification of production associated with the presence of mechanical milking can favor the transmission of the disease, since deficiencies in herd management (especially udder health) and disinfection and maintenance of milking equipment can facilitate transmission of the virus, which can be found in the milk of infected cows [15].

The increase in calf mortality observed in the herds that were seroreactive to EBL can be associated with the immunosuppression of the calf, since studies have demonstrated that newborn calves infected experimentally with BLV have lower levels of IgM and T lymphocytes in the blood [18]. The immunosuppression of the mother leads to the production of colostrum with worse quality, which can make the calf more susceptible to secondary infections. To reduce the risk of vertical transmission, calves born to mothers that are EBL carriers should be fed with colostrum and milk from cows that are negative for the virus or with pasteurized milk [1]. Nevertheless, EBL is not considered a disease that causes neonatal mortality [25]. Therefore, the findings in this study can be related to the inadequate management of newborn calves, not just to BLV.

A larger number of reproductive problems was observed in the animals that were seroreactive to EBL (Table 5). Stillbirth, repetition of estrus, retention of the placenta and uterine infection were the alterations observed most often. Animals seroreactive to EBL can take approximately 48 days longer for a new successful conception compared to non-reactive animals [9]. In this context, the greatest losses related to EBL are the reduction of milk yield, longer interval between calving and premature culling of animals [6].

There was no association between EBL and the reproductive management (natural mounting or artificial insemination) in our study. Experiments carried out with biological materials with reproductive importance, such as semen and ovules from animals infected by the EBL virus, indicate that these materials have little importance in the transmission of the agent [16]. The milk production level of the farms also was not associated with EBL.

\section{CONCLUSION}

Enzootic bovine leukosis is disseminated in the dairy herds in the municipalities that compose the Caparaó region of Espírito Santo. In these herds, the occurrences of clinical mastitis, subclinical mastitis, calf mortality and presence of reproductive problems were high. The reuse of disposable needles and use of mechanical milking were found to be risk factors associated with enzootic bovine leukosis. Reproductive management (artificial insemination versus natural mounting) and level of milk production by the farm were not associated with EBL.

\section{MANUFACTURERS}

${ }^{1}$ DifcoTM Noble Agar. Sparks, NV, USA.

${ }^{2}$ Tecpar® antigens. Curitiba, PR, Brazil.

${ }^{3}$ Open Source Epidemiologic Statistics for Public Health. Atlanta, GA, USA.

Acknowledgements. This study received support from the Espírito Santo Foundation to Support Research and Innovation (FAPES, process 65921615/14) and the Office to Coordinate Improvement of University Personnel (CAPES, finance code 001). Facilities were provided by Espírito Santo Federal University (UFES) and Darcy Ribeiro Norte Fluminense State University (UENF) in Rio de Janeiro.

Ethical approval. Research on animals was conducted according to the institutional committee on animal use of the Federal University of Espirito Santo (protocol number 003/2015). Informed consent has been obtained for client-owned animals included in this study.

Declaration of interest. The authors report no conflicts of interest. The authors alone are responsible for the content and writing of paper.

\section{REFERENCES}

1 Acaite J., Tamosiunas V., Lukauskas K., Milius J. \& Pieskus J. 2007. The eradication experience of enzootic bovine leukosis from Lithuania. Preventive Veterinary Medicine. 82(1-2): 83-89.

2 Ambrósio N.A. 2015. Intercorrência da leucose enzoótica bovina e mastite em vacas leiteiras naturalmente infectadas. 93f. Lavras, MG. Dissertação (Mestrado em Ciências Veterinárias) - Programa de Pós-Graduação em Ciências Veterinárias, Universidade Federal de Lavras. 
3 Assis H.A., Barioni G., Starling R.Z.C. \& Donatele D.M. 2015. Ocorrência da Leucose Enzoótica no gado bovino abatidos sob Inspeção estadual no Estado do Espírito Santo no ano de 2013. Pubvet. 9(4): 163-168.

4 Barros Filho I.R., Guimarães A.K., Spnchiado D., Krüger E.R., Wammes E.V., Ollhoff R.D., Dornbusch P.T. \& Biondo A.W. 2010. Seroprevalence de anticorpos para o vírus da Leucose Enzoótica em bovinos criados na região metropolitana de Curitiba, Paraná. Arquivos do Instituto Biológico. 77(3): 511-515.

5 Barros G.S.A.C., Galan V.B., Guimarães V.A. \& Bacchi M.R.P. 2001. Sistema agroindustrial do leite no Brasil. Brasília: Embrapa, pp.100-172.

6 Bartlett P.C., Norby B., Byrem T.M., Parmelee A., Ledergerber J.T. \& Erskine R.J. 2013. Bovine leukemia virus and cow longevity in Michigan dairy herds. Journal of Dairy Science. 96(3): 1591-1597.

7 Batista Filho L.C.F., Fernandes A.C.C., Silva T.I.B., Ramos T.R.R. \& Melo L.E.H. 2019. Performance assessment of imported ELISA in the serodiagnosis of the enzootic bovine leukosis in herds of Pernambuco state, Brazil. Arquivos do Instituto Biológico. 86: 1-4.

8 Botaro B. \& Santos M.V. 2008. O impacto silencioso da mastite subclínica. Disponível em: <https://www.milkpoint. com.br/colunas/marco-veiga-dos-santos/o-impacto-silencioso-da-mastitis-subclinica-46148n.aspx>.

9 Brenner J., Van-Haam M., Savir D. \& Trainin Z. 1989. The implication of BLV infection in the productivity, reproductive capacity and survival rate of a dairy cow. Veterinary Immunology and Immunopathology. 22(3): 299305.

10 Carillo H.A.M., Silveira S.R.B., Miranda A.S., Rodrigues E.D.L. \& Salvarani F.M. 2019. Prevalence of bovine brucellosis, paratuberculosis, enzootic leucosis, and antigen-reactive agents to bovine viral diarrhea virus in animals up to one year old. Semina: Ciências Agrárias. 40(1): 485-490.

11 Castro B.G., Souza M.M.S. \& Bittencourt A.J. 2012. Prevalência e etiologia da subclinical mastitis na região sul fluminense. Revista Acadêmica Ciências Agrárias e Ambientais. 10(3): 263-268.

12 Fernandes C.H.C., Melo L.E.H., Tenório T.G., Mendes E.I., Fernandes A.C., Ramalho T.R.R., Moura Sobrinho P.A. \& Mota R.A. 2009. Soroprevalência e fatores de risco da infecção pelo virus da Leucose dos bovinos em rebanhos leiteiros da região Norte do estado do Tocantins, Brasil. Arquivo do Instituto Biológico. 76(3): 327-334.

13 Frie M.C. \& Coussens P.M. 2014. Bovine leukemia virus: A major silent threat to proper immune responses in cattle. Veterinary Immunology and Immunopathology. 163(3-4): 103-114.

14 Instituto Brasileiro de Geografia e Estatística (IBGE). 2019. Pesquisa da Pecuária Municipal 2015. Disponível em: $<$ https://www.ibge.gov.br/estatisticas/economicas/agricultura-e-pecuaria.html>

15 Jaworski J.P., Porta N.G., Gutierrez G., Politzki R.P., Álvarez I., Galarza R., Abdala A., Calvinho L. \& Trono K. G. 2016. Short communication: Relationship between the level of bovine leukemia virus antibody and provirus in blood and milk of cows from a naturally infected herd. Journal of Dairy Science. 99(7): 5629-5634.

16 Johnson R. \& Kaneene J.B. 1992. Bovine Leukaemia Virus and Enzootic Bovine Leukosis. Veterinary Bulletin. 62(4): 287-312.

17 Kakinuma S., Marda Y., Ohtsuka H., Konnai S. \& Oikawa M. 2014. Bovine Leukemia virus titer and leukocyte population associated with mastitis in periparturient dairy cows. International Journal of Applied Research in Veterinary Medicine. 12(3): 239-244.

18 Meirom R., Moss S. \& Brenner J. 1997. Bovine leukemia virus-gp51 antigen expression is associated with CD5 and IgM markers on infected lymphocytes. Veterinary Immunology and Immunopathology. 59(1-2): 113-119.

19 Organização Internacional de Epizootias (OIE). 2009. World Organisation for Animal Animal Health. World Animal Health Information Database - Version: 1.4. Paris, France: World Organisation for Animal Health. Disponível em: $<$ https://www.oie.int/fileadmin/Home/eng/Our_scientific_expertise/reflabreports/2018/report_594_2018_Enzootic_bovine_leukosis>

20 Oliveira A.J., Moraes G.F., Ferreira I.C., Monteiro C.P. \& Carvalho A.D.F. 2013. Mastite clínica e subclínica em pequenas propriedades leiteiras no município de Araguari - MG. Veterinária Notícias. 19(1): 7-13.

21 Oliveira C.M.C., Sousa M.G.S., Silva N.S., Medonça C.L., Silveira J.A.A., Oaigen R.P., Andrade S.J.T. \& Barbosa J.D. 2011. Prevalência e etiologia da mastite bovina na bacia leiteira de Rondon do Pará, estado do Pará. Pesquisa Veterinária Brasileira. 31(2): 104-110.

22 Philpot W.N. \& Nickerson S.C. 2002. Vencendo a luta contra a mastite. São Paulo: Jaguariuna Westfalia Landtechinic do Brasil, 192p. 
I.C. Almeida, S.L.H. Almeida, G. Barioni, et al. 2021. Seroprevalence and Influence of Bovine Leukemia Virus on the Incidence of Mastitis in Dairy Herds. Acta Scientiae Veterinariae. 49: 1783.

23 Rajão D.S., Heinemann M.B., Reis J.K.P., Braz G.F., Haddad J.P.A., Ribeiro A.C.C.L. \& Leite R.C. 2014. Effects of bovine leukemia virus infection on crossbred and purebred dairy cattle productive performance in Brazil. Semina: Ciências Agrárias. 35(2): 891-900.

24 Rodríguez S.M., Florins A., Gillet N., Brogniez A., Sánchezalcaraz M.T., Boxus M., Boulanger F., Gutiérrez G., Trono K., Alvarez I., Vagnoni L. \& Willems L. 2011. Preventive and therapeutic strategies for Bovine Leukemia Virus: Lessons for HTLV. Viruses. 3(7): 1210-1248.

25 Ruiz V., Porta N.G., Lomónaco M., Trono K. \& Alvarez I. 2018. Bovine leukemia virus infection in neonatal calves. Risk factors and control measures. Frontiers in Veterinary Science. 5(267): 1-7.

26 Sandev N., Koleva M., Binev R. \& Ilieva D. 2004. Influence of enzootic bovine leukosis virus upon the incidence of subclinical mastitis in cows at a different stage of infection. Veterinarski Archiv. 74(6): 411-416.

27 Schwartz I. \& Lévy D. 1994. Pathobiology of bovine leukemia virus. Veterinary Research. 25(6): 521-536.

28 Starling R.Z.C., Bezerra A.O., Salardane I., Ferreira P.G., Clipes R.C. \& Donatele D.M. 2013. Soroepidemiologia da leucose enzoótica bovina em propriedades leiteiras do municipality de Alegre, estado do Espírito Santo, Brasil. Jornal Brasileiro de Ciência Animal. 6(12): 427-441.

29 Vieira B.C.R., Lorenzoni L.S., Souza M.H., Alfaiate M.B. \& Xavier T.M.T. 2013. Etiologia infecciosa associada a mastite subclínica em bovinos de propriedades rurais no município de Alegre-ES. Enciclopédia Biosfera. 9(16): 11541172.

30 Vissio C., Aguero D.A., Rawspanti C.G., Odierno L.M. \& Larriestra A.J. 2015. Pérdidas productivas y económicas diárias ocasionadas por la mastitiss y erogaciones derivados de su control em estabelecimentos lecheros de Córdoba, Argentina. Archivos de Medicina Veterinaria. 47(1): 7-14. 